\title{
ARTIKKELIT
}

\section{У Vartoomista, korpeentumista, rämpimistä - palvelutalossa asuvien kokemuksia yksinäisyydestä}

\author{
Anu Jansson ${ }^{1}$, Antti Karisto ${ }^{2}$, Kaisu Pitkälä1,3

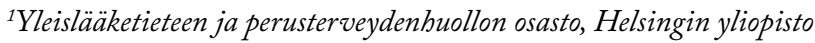 \\ ${ }^{2}$ Helsingin yliopisto \\ ${ }^{3}$ HUS Perusterveydehuollon yksikkö
}

\begin{abstract}
Tutkimuksen tarkoituksena oli tarkastella palvelutalossa asuvien iäkkäiden yksinäisyyttä: miten yksinäisyys koetaan ja ilmaistaan sekä miten se kontekstualisoituu ajallisesti ja paikallisesti. Aineisto kerättiin etnografisen tutkimuksen antaman mallin mukaisesti yksilö- ja ryhmähaastatteluin sekä havainnoimalla. Analysointi tapahtui abduktiivista päättelyä hyödyntäen sekä grounded theorylle tyypillistä kategorisointia soveltaen.

Yksinäisyys osoittautui hyvin yksilölliseksi, mutta samalla aikaan ja paikkaan sidoksissa olevaksi kokemukseksi. Palvelutaloympäristölle tyypillinen elämänrytmi ja toimintakäytänteet heijastuivat kokemuksiin. Yksinäisten aika oli jokseenkin tapahtumaköyhää, alituista odottamista. Yksinäisyys oli sidoksissa vuorokaudenaikaan, viikonpäiviin ja vuodenaikoihin. Yksinäisyys kumpusi siitä, että palvelutaloasuntoa ei pidetty omana kotina, ei välttämättä edes kodinomaisena paikkana. Siellä jouduttiin viettämään pitkiä aikoja yksin eikä ulos päästy niin usein kuin olisi haluttu. Vuorovaikutus talon toisten asukkaiden kanssa oli toivottua vähäisempää, ja osa asukkaista koki itsensä näkymättömäksi.

Aikaan ja paikkaan sidotut yksinäisyyskokemukset ovat tärkeitä signaaleja, jotka tulisi ottaa huomioon palvelutaloasumista ja toimintaa suunniteltaessa. Yksinäisyyden ennaltaehkäisy ja lievittäminen on olennaista.
\end{abstract}

\section{Johdanto}

Yksinäisyys on ihmiselle henkilökohtainen ja useimmiten kielteinen kokemus, joka voi tuottaa kosolti kärsimystä. Yksinäisyyden aiheuttamaa painolastia kasvattavat sen ilmeiset yhteydet terveyteen ja hyvinvointiin, kuten kognition ja fyysisen toimintakyvyn heikentymiseen
(Cacioppo \& Hawkley 2009; Savikko, Jansson ja Pitkälä 2019), depressioon (Luanaigh \& Lawlor 2008; Smith \& Victor 2018) sekä lisääntyneeseen kuolemanvaaraan (Tilvis ym. 2011; Drageset ym. 2012) ja terveyspalveluiden käyttöön (Gerst-Emerson \& Jayawardhana 2015). Suomessa noin $20-40$ prosenttia kotona asuvista iäkkäistä kertoo kokevansa yksinäi- 
syyttä vähintään toisinaan, kymmenisen prosenttia usein tai aina (Savikko ym. 2005, Yang \&Victor 2011; Vaarama ym. 2014, Saari 2016).

Yksin asuminen ennustaa yksinäisyyttä (Routasalo ym. 2006), mutta samoja asioita ne eivät ole. Yksin asuva ei välttämättä ole yksinäinen, ja yksinäisyyttä voidaan kokea myös asuttaessa muiden kanssa. Esimerkiksi palvelutalossa asutaan lähellä muita ihmisiä, mutta yksinäisyyttä voi sielläkin ilmetä. Yksinäisyys voi jopa kärjistyä, jos entiset ihmissuhteet ohentuvat eikä uuteen asuinympäristöön kotiuduta kunnolla (Savikko ym. 2005).

Iäkkäiden yksinäisyyttä on tutkittu viime aikoina paljon, mutta harvat tutkimukset ovat kohdistuneet tässä kiinnostuksen kohteena olevaan palvelutaloympäristöön. Viitteitä on kuitenkin siitä, että yksinäisyys on myös palvelutaloissa asuvien rasitteena. Esimerkiksi Dragesetin ja kumppaneiden (2011) tekemässä tutkimuksessa yli puolet (56\%) norjalaisten hoitokotien 75 vuotta täyttäneistä asukkaista kertoi olevansa yksinäinen usein tai toisinaan. Helsinkiläisissä palvelutaloissa asuvista iäkkäistä kymmenesosa (9\%) kärsi yksinäisyydestä usein ja neljäsosa (26 \%) toisinaan (Jansson ym. 2017). Yli puolet 85 vuotta täyttäneistä hoitoja ryhmäkotien asukkaista Pohjois-Ruotsissa ja läntisessä Suomessa kokivat itsensä yksinäiseksi vähintään toisinaan (Nyqvist ym. 2013).

Yksinäisyyden yleisyys siis vaihtelee, joskin osa havaitusta vaihtelusta johtuu eroista tutkimusasetelmissa, yksinäisyyden määrittelyssä ja mittaustavoissa. Useimmat tutkimukset ovat tuottaneet arvioita jollakin tavoin dikotomisoidun yksinäisyyden yleisyydestä. Yksinäisyys ei kuitenkaan ole asia, jota joko on tai ei ole. Siksi yksinäisyyden kokemuksia on syytä eritellä tarkemmin myös laadullisen tutkimuksen keinoin (Brownie \& Horstmanshof 2011; Tiilikainen \& Seppänen 2017; Smith \& Victor 2018).

Yksinäisyyden tutkiminen on arvokasta itsessään, mutta yksinäisyystutkimuksella voi myös olla annettavaa esimerkiksi hoivakäytäntöjä arvioitaessa. Palvelutalojen pyrkimyksenä on tarjota kodinomaista asumista iäkkäille ih- misille, edistää elämänlaatua sekä kunnioittaa yksilöllisyyttä ja autonomiaa (Roth \& Eckert 2011). Palvelutaloissa pyritään asiakaslähtöiseen, yhteisölliseen sekä kuntouttavaan työotteeseen ja toimintakäytäntöihin. Tavoitteena on, että elämä on turvallista, arvokasta ja merkityksellistä (Laki ikääntyneen väestön toimintakyvyn tukemisesta sekä iäkkäiden sosiaali- ja terveyspalveluista 980/2012). Käytäntö ei vain aina vastaa tavoitteita (Pirhonen 2017).

Vaikka palvelutalossa asutaan fyysisesti lähellä toisia ihmisiä, henkisesti voidaan silti olla heistä etäällä. Pirhonen, Tiilikainen ja Pietilä (2017) kuvaavat palvelutalossa vallitsevan yhteisöllisyyden haurautta. Suhteet talon ulkopuolella asuviin sukulaisiin ja ystäviin ovat ohentuneet, eikä kunnon yhteyttä talon muihin asukkaisiin ja henkilökuntaan ole syntynyt. Vaikka asuminen palvelutalossa on turvallista ja omaistenkin huoli on voinut haihtua, yllättävän yksinäiseltä voi sielläkin tuntua (Slettebø 2008).

Yksinäisyystutkimuksen kohteena palvelutalo on erityisen mielenkiintoinen paikka, sillä se sijoittuu jonnekin kodin ja laitoksen välimaastoon (Roth ja Eckert 2011). Yksinäisyyttä tutkittaessa tulee yleensäkin tarkastella myös sen kontekstia - sitä jokapäiväistä ympäristöä, jossa eletään ja johon kokemukset ja tuntemukset paikantuvat.

\section{Tutkimuksen tavoite, konteksti, aineisto ja menetelmät}

Tässä tutkimuksessa keskitytään siihen, miten yksinäisyyden kokemukset ilmenevät palvelutalossa ja sille tyypillisessä arkielämän rytmissä. Tutkimus on osa laajempaa kokonaisuutta, jossa selvitetään yksinäisyyden yleisyyttä, siihen yhteydessä olevia tekijöitä, yksinäisyyden ennustetta sekä sen lievittämiseksi tehtyjä interventioita (Jansson ym. 2017; Jansson, Savikko \& Pitkälä 2018; Jansson, Karisto \& Pitkälä 2019a, 2019b). Tässä artikkelissa kuvaamme, miten palvelutalossa asuvat iäkkäät ihmiset kokevat ja ilmaisevat yksinäisyyttä. Kysymme, 
miten yksinäisyys kontekstualisoituu ajallisesti ja paikallisesti, ja miten se on yhteydessä palvelutalolle tyypilliseen elämisen rytmiin ja palvelutaloon paikkana.

Tavoitteenamme on saada palvelutalossa asuvien oma ääni kuuluville. Aineistoja hankkiessamme olemme koettaneet päästä tutkimuskohteemme lähelle kuuntelemalla palvelutalon asukkaita herkällä korvalla. Aineistojen kerääminen on edellyttänyt eläytymistä, niiden tulkinta ja taas analyyttista etäisyyden ottamista (Karisto 2008,39-42). Kenttätyön on tehnyt meistä yksi (AJ), mutta kirjoittajia on kolme. Työnjako ei kuitenkaan ole ollut mekaaninen, sillä emme ole hahmottaneet kenttätyötä ja kirjoittamista täysin erillisiksi tutkimuksenteon vaiheiksi. Niiden välille kovin helposti avautuvaa kuilua olemme koettaneet kuroa umpeen "antropologisen itsereflektion" keinoin (Aro 1996, 29-30), kirjoittamalla mahdollisimman empaattisesti.

\section{Valoisa talo ja pitkä talo}

Tutkimus toteutettiin kahdessa helsinkiläisessä tehostetun palveluasumisen yksikössä, joita kutsumme jatkossa lyhyesti palvelutaloiksi. Molempien talojen tavoitteena on tarjota asukkailleen turvallista, aktiivista, kuntouttavaa ja laadukasta asumista. Niiden esitteissä ja kirjallisissa tavoitelausumissa puhutaan paljon hoivatyön asiakaslähtöisyydestä sekä asiakkaan yksilöllisyyden ja autonomian kunnioittamisesta. Talojen fyysisissä puitteissa on selviä eroja. 1980luvulla rakennetun "valoisan talon" tilat ovat raikkaat, aikaisemmin rakennetun ja myöhemmin palvelutaloksi muutetun "pitkän talon" tilat ovat taas vieraannuttavalla tavalla hämyisät. Muuan pitkän talon asukas kuvasi asuinmiljöötään näin: Tää talo on pitkä ku nälkävuosi. Ei tiedä mistä se alkaa ja mibin se loppuu. Talon pitkät käytävät eivät vetäneet puoleensa, havainnointipäivien aikana niillä näkyi harvoin ketään. Sen sijaan valoisan talon käytävillä ja auloissa nähtiin usein hoitajia, sukulaisia ja vapaaehtoistyöntekijöitä asukkaiden kanssa.
Asukkaiden keskinäinen vuorovaikutus vaikutti tosin valoisassakin talossa vähäiseltä.

Henkilökuntaa on molemmissa taloissa suunnilleen sama määrä. Johtajan lisäksi on siivoojia, keittiöhenkilökuntaa, hoitajia, fysioterapeutti, toimintaterapeutti sekä virike- ja sosiaaliohjaajia. Talojen palveluvarustuskin on jokseenkin samankaltainen. Molemmissa taloissa on sauna, kuntosali, ruokailutila, harrastetila sekä erilaisia ryhmätiloja. Käytävillä on television katseluun ja oleskeluun tarkoitettuja sohvaryhmiä. Molemmissa palvelutaloissa on sekä yhden että kahden hengen asuntoja, jotka ovat noin 30 neliömetrin suuruisia. Muistisairaille asukkaille on oma ryhmäkotinsa. Asunnot on saanut sisustaa pääpiirteissään omien toiveiden mukaisesti.

\section{Tutkittavat}

Tutkimus toteutettiin eettisiä ohjeita (HUS 1150/2016 ja HEL 2016-014058) huolellisesti noudattaen. Talojen henkilökuntaa ja asukkaita informoitiin jo tutkimuksen käynnistymisestä suullisesti sekä kirjallisin tiedottein. Etukäteen tapahtuneen yleisen tiedottamisen jälkeen lähestyimme palvelutalojen yksittäisiä asukkaita henkilökunnan kautta rekrytoidaksemme heitä mukaan tutkimukseen. Potentiaaliset osallistujat ja heidän omaisensa saivat kirjeitse tietoa tutkimuksesta ja sen aineistonkeruusta. Tähdensimme, että tutkittavilla on oikeus kieltäytyä tutkimuksesta ja myös peruuttaa jo antamansa suostumus tutkimukseen osallistumisesta, milloin tahansa syytä ilmoittamatta.

Tutkimukseen osallistui yhteensä kolmetoista palvelutalojen iäkästä asukasta, joiden taustaominaisuuksia on kuvattu taulukossa 1.Pitkästä talosta tutkimukseen osallistui seitsemän asukasta,jotka olivat kognitiivisesti toimintakykyisiä (MMSE 25-30). Fyysisiltä puitteiltaan paremmasta valoisasta talosta osallistui kuusi asukasta, joilla oli varhais- ja varhaiskeskivaiheen muistisairaus (MMSE 15-23). Halusimme tieten tahtoen tutkittaviksi myös muistisairaita, sillä heitä asuu palvelutaloissa paljon. 
Taulukko 1. Vastaajien perustiedot

\begin{tabular}{lll}
\hline Vastaajat & Pitkä talo & Valoisa talo \\
\hline Naisia & 7 & 4 \\
Miehiä & 0 & 2 \\
Ikä, keskiarvo (vaihteluväli) & $80(72-87)$ & 88 (82-94) \\
Siviilisääty & & \\
- Naimisissa & 0 & 1 \\
- Naimaton & 1 & 1 \\
- Eronnut & 2 & 2 \\
- Leski & 4 & 2 \\
Kansakoulu tai vähemmän & 3 & 5 \\
Yksinäisyyden kokemus & & \\
- toisinaan & 5 & 6 \\
- usein tai aina & 2 & 20 (15-23) \\
MMSE, keskiarvo (vaihteluväli) & 28 (25-30) \\
\hline
\end{tabular}

Tärkein osallistujien sisäänottokriteeri oli kokemus yksinäisyydestä, jota kartoitimme esitietolomakkeen kysymyksellä "kärsittekö yksinäisyydestä?”. Vastausvaihtoehdot olivat: harvoin tai ei koskaan/toisinaan/usein tai aina. Kysymystä on käytetty useissa aikaisemmissa tutkimuksissa, jolloin on huomattu, että iäkkäiden ihmisten on helppo ymmärtää se ja vastata siihen (mm. Savikko 2008; Tilvis ym. 2011). Tutkimukseen otettiin mukaan ne, jotka kertoivat kärsivänsä yksinäisyydestä vähintään "toisinaan". Kolmella henkilökunnan ehdottamalla asukkaalla sisäänottokriteeri yksinäisyyden kokemuksesta ei täyttynyt. Ennakkotietolomakkeessa kysyttiin myös ikää, siviilisäätyä ja koulutustasoa. Kaksi vastaajaa täytti lomakkeen hoitajan avustuksella, muut itsenäisesti.

\section{Aineistonkeruu}

Tutkimuksessa käytettiin useita erilaisia erityisesti etnografiselle tutkimukselle tyypillisiä aineistonkeruumenetelmiä. Artikkelin ensimmäinen kirjoittaja $(\mathrm{AJ})$ otti puolen vuoden ajan tuntumaa tutkittavien arkeen yksilöhaastattelujen, ryhmätapaamisten, epämuodollisten keskustelujen ja havainnoinnin avulla. Tutkit- tavia lähestyttiin ensin puolistrukturoituja teemahaastatteluja tekemällä. Nämä yksilöhaastattelut kestivät puolesta puoleentoista tuntiin ja olivat luonteeltaan keskustelunomaisia. Haastateltavat kertoivat kokemuksistaan ja tunteistaan jokseenkin avoimesti.

Noin kolme viikkoa yksilöhaastattelujen jälkeen tutkittavat osallistuivat palvelutaloissa järjestettyihin Ystäväpiiri-ryhmiin, joiden tarkoituksena oli lievittää heidän yksinäisyyttään (Jansson ym. 2018). Molemmissa taloissa ryhmät kokoontuivat kerran viikossa kolmen kuukauden ajan. Ryhmiä ohjasivat koulutetut ryhmänohjaajat. Yksi kirjoittajista (AJ) havainnoi ryhmäprosesseja ja pääsi kolmesti kuulemaan, miten osallistujat sanoittivat yksinäisyyden kokemuksiaan ryhmätapaamisissa. Havainnoinnit ajoitettiin ryhmäprosessin alkuun, keskivaiheille ja loppuun. Niiden puitteissa käydyt vapaamuotoiset keskustelut nauhoitettiin ja litteroitiin.

Noin kahdesta neljään viikkoa ryhmäprosessin jälkeen osallistujat haastateltiin jälleen. Toisen kierroksen yksilöhaastatteluja toteutettaessa otettiin vaikutteita laadullisesta pitkittäistutkimuksesta (Nikander 2014; Tiilikainen 2016), olihan tutkittavilla ollut aikaa ilmaista ja työstää yksinäisyyden kokemuksiaan ja 
niissä mahdollisesti tapahtuneita muutoksia. Käytännössä haastatteluissa palattiin usein ensimmäisissä yksilöhaastatteluissa ja ryhmätapaamisissa kuultuihin kokemuksiin, joita käytiin läpi, niitä uudelleen laajentamalla ja syventämällä. Myös toisen kierroksen nauhoitettujen haastattelujen kesto vaihteli puolesta puoleentoista tuntiin.

Haastattelija (AJ) koetti parhaansa mukaan paneutua tutkittavien tapaamisiin. Haastattelutuokiot alkoivat usein niin, että ensin ikään kuin yhteistuumin järjesteltiin tiloja jutustelua varten. Raivattiin lehtikasa tuolin päältä, siirrettiin likaiset astiat rollaattorin istumatasolta tiskipöydälle. Sitten puhetta alkoi pulputa. Haastattelija kuunteli tarkkaavaisesti (Heyl 2001) eikä keskeyttänyt hiljaisiakaan hetkiä.

Käytännön tehtäviä tehdessä minulle tuli asukkaan kotona tunne siitä, että hän kyseli sanallisesti ja sanattomastikin, kannattaako minuun luottaa tai ylipäätään ryhtyä juttusille. Asukas otti ohjat käsiinsä haastatteluun valmistauduttaessa. Hän saneli mikä lehti jätetään pöydälle ja mikä puolestaan joutaa roskakoriin. Kun olin raivannut paikat hänen mielensä mukaisesti, hän tokaisi tyytyväisenä, että "no nythän me tässä vasta päästään alkuun". (Ote kenttäpäiväkirjasta)

Ennen haastattelua haastattelijan oli otettava ruumiillistakin tuntumaa toiseen, oli asettauduttava asukkaan arkiseen rytmiin, pysähtyneisiinkin hetkiin. Haastatteluja tehtäessä oli osallistuttava myös avustaviin tehtäviin.

Kun soitin ovikelloa, ovi avautui usean minuutin kuluttua. Esittelin itseni ja kättelimme, mutta asukas jäi tai juuttui oven eteen seisomaan. Minun oli tuettava häntä kävelyssä. Kolmen metrin kävelymatka kesti useita minuutteja, istumaan auttaminen vielä saman verran lisää. Kävelyn aikana emme voineet juurikaan keskustella. Aina kun hän kuuli ulkopuolisen ärsykkeen tai kun erehdyin sanomaan jotain, kävely keskeytyi ja asukkaan piti keskittyä uudelleen yksittäisen askeleen ottamiseen tai jalan siirtämiseen. Kun tuolille päästiin, asukas huokaisi helpotuksesta. (Ote kenttäpäiväkirjasta)

Aineistonkeruun viimeinen vaihe oli fokusryhmähaastattelu, joka tehtiin molemmille ryhmille 3-4 viikkoa yksilöhaastattelujen jälkeen. Tavoitteena oli kohdentaa ryhmän keskustelu yksinäisyyteen ja kartoittaa jaettuja kokemuksia. Hienosti sanoen "ryhmän moderaattori (AJ) fasilitoi" asukkaiden välistä keskustelua, mutta käytännössä hänen ei tarvinnut niin paljon ponnistella kuin joitakin yksilöhaastatteluja aloitettaessa. Ryhmäkeskustelutilanteet olivat jo tutuiksi tulleiden ihmisten luonnollisia tapaamistilanteita, joissa "moderaattori" koetti vain pitää huolen siitä, että puheet eivät karanneet kauaksi itse aiheesta, yksinäisyydestä. Ryhmäkeskustelut syvensivät hyvin yksilöhaastatteluja, sillä niissä tartuttiin myös toisten esille nostamiin asioihin ja ajatuksiin; kerrottiin omista kokemuksista ja yhteistä teemaa valaistiin monista yksilöllisistä näkökulmista (Mäntyranta \& Kaila 2008). Fokusryhmähaastattelun kesto oli tunti neljäkymmentä minuuttia molemmissa ryhmissä.

Koko aineisto kerättiin kuuden kuukauden aikana, ja siihen sisältyi 26 yksilöhaastattelua, 27 palvelutalokäynnillä tehtyjä yksilöhavaintoja, kuusi ryhmähavainnointia ja kaksi fokusryhmähaastattelua. Yksilö- ja ryhmähaastattelut litteroitiin tarkasti, mukaan lukien täytesanat ja tauot. Litterointeja kertyi 810 sivua (Times New Roman, 1-riviväli). Havainnointiaineisto puolestaan koostui noin 50 sivusta käsin kirjoitettuja muistiinpanoja.

\section{Analyysi}

Aineiston analyysi alkoi niin, että luimme litteroinnit useampaan kertaan läpi saadaksemme yleistä ymmärrystä tutkimastamme ilmiöstä. Myös havainnoinnista tehdyt muistiinpanot olivat käytössä, ja ne auttoivatkin rekonstruoimaan haastattelutilanteiden tunnelmia. 
Kun haastateltavalta kysyttiin yksinäisyydestä, bänelle tuli kyyneleet silmiin. Samalla myös haastattelija herkistyi. Hiljaisen hetken jälkeen haastateltava alkoi kertoa yksinäisyydestään hitaasti ja tunteikkaasti, sana kerrallaan. (Ote kenttäpäiväkirjasta)

Vastataksemme tutkimuskysymyksiin analysoimme aineistoa Atlas.ti -ohjelmiston avulla (Hwang 2008). Seuloimme esille kaikkiaan 106 yksinäisyyteen liittyvää aineisto-otetta, "yksinä..." -johdoksia sekä "yksin"-sanan yksinäisyyttä kuvaavia ilmauksia (esim. olen niin $y k s i n)$. Aineiston näin tehty seulonta alkoi kuitenkin näyttää mekaaniselta, sillä yksinäisyydestä puhuttiin paljon myös muilla sanoilla, hyvinkin omintakeisesti, usein murteelliseen tai persoonalliseen kielenkäyttöön tukeutuen. Jonkin verran puhuttiin myös yksin olemisen myönteisistä merkityksistä, mutta nämä aineisto-otteet jätimme analyysin ulkopuolelle ja keskityimme ongelmallisina pidettyihin $y \mathrm{k}-$ sinäisyyden kokemuksiin.

Käydessämme litteroinnit läpi rivi riviltä, löytyi 546 aineisto-otetta, joissa oli esillä yksinäisyyteen liittyviä ilmauksia ja episodeja. Ryhmiteltyämme niitä ja etsittyämme niiden välisiä polkuja tuntui siltä, että näin on saataisi luotua hyvä yleiskuva palvelutalossa asuvien yksinäisyydestä ja samalla heidän jokapäiväisestä elämästään. Samat asukkaat kuvasivat yksinäisyyttään samankaltaisesti tiedonkeruun eri kohdissa. Erityisesti varhais- ja varhaiskeskivaiheen muistisairaat toistivat usein samasanaisesti jo aikaisemmin lausumaansa. Toisto kasvatti esille tulleiden ilmausten painoarvoa, mutta toisaalta se kasvatti myös aineistoa. Joskus yksinäisyyttä koskeva toisteinen puhe tuntui muuttuvan jopa kliseiseksi, mutta siihenkään emme suhtautuneet vähättelevästi tai pitäneet sitä tyhjänä puheena.

Tarkemman analyysin kohteeksi valitsimme 90 erilaista aineisto-otetta. Niissä oli edus- tajia niin usein toistuneista ilmauksista kuin omintakeisista kokemusten kuvauksista. Joukossa oli lyhyitä kokemusten kiteytyksiä ja pitempiä, yksinäisyyttä kontekstualisoivia ja merkityksellistäviä kokonaisuuksia.

Analyysi oli pääosin, mutta ei puhtaasti induktiivista. Siihen, mitä aineistosta näimme, vaikutti myös aikaisemmista tutkimuksista peräisin oleva tietämyksemme iäkkäiden yksinäisyydestä. Analyysia voikin kutsua abduktiiviseksi. Palvelutaloasukkaiden kerronta - yksinäisyyden eksplisiittiset kuvaukset, mutta myös kerronnan rytminen vaihtelu hiljaisine hetkineen ja vasta havainnoinnin paljastamine tunteineen - antoi vihjeitä siitä, mitkä asiat olivat haastateltaville erityisen merkityksellisiä ja mitä he yksinäisyydestään oikein ajattelivat. Aineisto-otteiden yhteyksien hahmottamisessa auttoi etukäteistieto, mutta se edellytti myös sensitiivistä suhtautumista aineistoon, ehkä jonkinlaista luovuuttakin (Mirza ym. 2014).

Valitut aineisto-otteet koodattiin ja koodit ryhmiteltiin kategorioiksi grounded theoryn antaman mallin (Charmaz \& Mitchell 2002, Foley \& Timonen 2015) mukaisesti. Kategoriat muodostettiin yhdistämällä selvästikin samasta asiasta kertovat ilmaukset. Monin erilaisin sanakääntein tuotiin esille esimerkiksi sitä, että "palvelutalo ei tunnu kodilta". Tälle kategorialle sukua olivat niin ikään useista yksittäisistä lausumista muodostuneet "yksityisyyden puute palvelutalossa", "yksinäiset tilat ja paikat" ja "rutiininomaiset vuorovaikutustilanteet asunnossa ja sen ulkopuolella”. Nämä neljä kategoriaa tuottivat yhdeksi ydinkategoriaksi päättelemämme" yksinäisyyden paikan”. Kaksi muuta ydinkategoriaa olivat samalla tavoin johdetut "yksinäisyys on sidoksissa aikaan" ja "yksinäisyyden yksilöllinen luonne". Koodauksen kulku, päättelypolut aineistoesimerkeistä ydinkategorioihin, on tiivistetty taulukkoon 2 . 
Taulukko 2. Koodauksen päättelypolut aineistoesimerkeistä ydinkategorioihin

\begin{tabular}{|c|c|c|}
\hline Aineisto-otteita (esimerkkejä) & Alakategoria & Ydinkategoria \\
\hline $\begin{array}{l}\text { Olen yksinäinen / Arki on niin yksinäistä. / No, se minun arki on vähän } \\
\text { sellasta yksinäistä. }\end{array}$ & Yksinäisyyttä & \multirow{4}{*}{$\begin{array}{l}\text { Yksinäisyyden } \\
\text { yksilöllinen } \\
\text { luonne }\end{array}$} \\
\hline $\begin{array}{l}\text { Kuin loskassa rämpimistä. / Korpeentumista. / No mä oon vähän semmonen } \\
\text {-yksinäinen ihminen. / Kyllähän mulla kokemuksia riittää mistä vois puhua, } \\
\text { mutta kun mä en oo ryhtyny, saanu sen aidan yli päästyä, joka estää mua } \\
\text { puhumasta. /Tuntuu joskus ihan, jotenkin pahalle että kun pitää yksin olla ja } \\
\text { ei oo kaveria kenen kanssa juttelis. }\end{array}$ & $\begin{array}{l}\text { Henkilölle } \\
\text { ominaista } \\
\text { puhetta }\end{array}$ & \\
\hline $\begin{array}{l}\text { Kaikki sitä tuntee ja sitä on aina. Ja just tää, tietysti ketkä on pyörätuolissa } \\
\text { ja sänkyyn sidottuna. Että heillä ehkä on enemmän sitä yksinäisyyttä. / En } \\
\text { minä sitä nyt koe... mutta aina välillä se iskee / Monellakin on se yksinäisyys } \\
\text { sitten niin voimakas että tuntee niin että on ihan yksin. / Varsinkin vanhat } \\
\text { ihmiset kaikki potee yksinäisyyttä, siis ainakin, jonkinlaista yksinäisyyttä }\end{array}$ & Kiertoilmauksia & \\
\hline $\begin{array}{l}\text {...tää mua vanhempi ikäluokka on tottunu ajattelemaan, että yksinäisyys } \\
\text { on paha ja ystävyys on hyvä. Se on vähän sellast kliseistä ajattelua. / Kai } \\
\text { sitä korpeentumista voi omalla tavallaan yksinäisyytenäkin pitää. / Minusta } \\
\text { käsite yksinäisyydestä on liian yksipuolinen. Korpeentuminen on sen } \\
\text { ilmenemismuoto. }\end{array}$ & $\begin{array}{l}\text { Puntaroitua } \\
\text { puhetta }\end{array}$ & \\
\hline
\end{tabular}

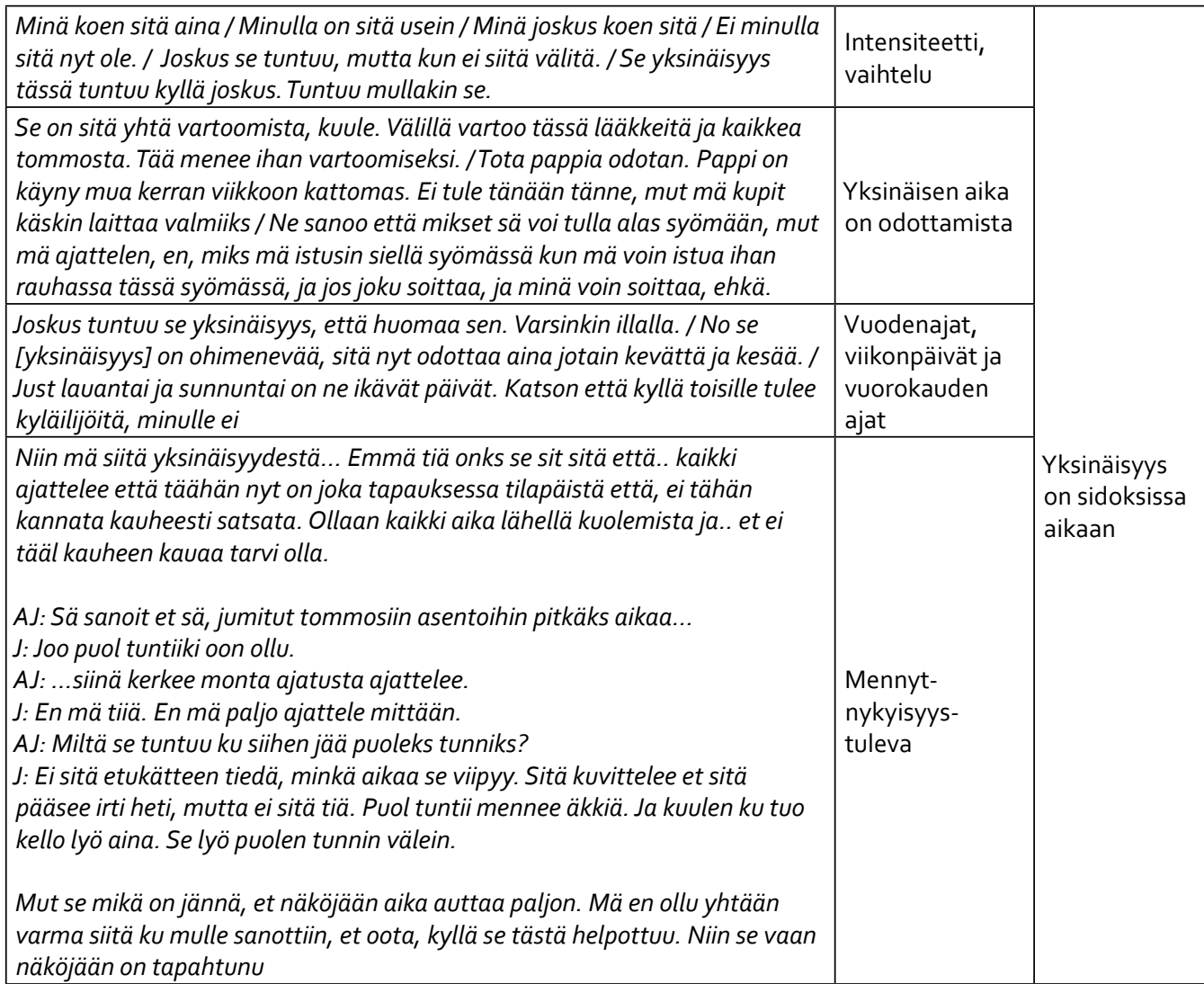




\begin{tabular}{|c|c|c|}
\hline Aineisto-otteita (esimerkkejä) & Alakategoria & Ydinkategoria \\
\hline $\begin{array}{l}\text { Joskus minä kaipaan sinne kotiin.. kaikki vanhat muistot elää siellä... / } \\
\text { sairaala / vankila / markkinatori / varasto / koppi / mökki / asunto / huone }\end{array}$ & $\begin{array}{l}\text { Palvelutalo ei } \\
\text { tunnu kodilta }\end{array}$ & \multirow{4}{*}{$\begin{array}{l}\text { Yksinäisyys } \\
\text { on sidoksissa } \\
\text { paikkaan }\end{array}$} \\
\hline $\begin{array}{l}\text { Joskus tulee ihan niin ettei koputa ja ei paina kelloo. / Minkä takia ku talossa } \\
\text { asuu niin ei kiinnitetä huomioo, et ihminen häviää? / Meidät pistetään } \\
\text { semmosiin lokeroihin. Luukusta ruokaa. / Paremmat niil on vankilassa } \\
\text { ku meil on oltavat. Pääsevät kaks kertaa viikossa suihkuun ja joka päivä } \\
\text { ulkoilutetaan /Tuli sitten uus asiakas ja hän oli nähny, että mä lähen. Se } \\
\text { sano että, saako täältä lähteeki johonkin. }\end{array}$ & $\begin{array}{l}\text { Yksityisyyden, } \\
\text { autonomian } \\
\text { puute } \\
\text { palvelutalossa }\end{array}$ & \\
\hline $\begin{array}{l}\text { Varsinki tällases paikkaa sitä voi tuntea olonsa välillä todella yksinäiseks. / } \\
\text { Sitte ku menee uvtena johonkin ryhmään, joka on jo koossa niin ei ole helppo } \\
\text { päästä sisään. Senhän takia ihmiset ei lähtiskään minnekään palvelutaloihin } \\
\text { ja vanhainkoteihin että ne olis kotona viimeseen saakka. / Mutta kun } \\
\text { yksinäisyys tulee, mihin mä voin mennä? En mihinkään. Pitäs olla joku } \\
\text { semmonen tila, missä vois istua mutta pitäs olla joku määrätty aika että } \\
\text { jokainen sitten joka halvaa, tulis silloin sinne. / Jos pääsee ulos niin ei silloin } \\
\text { ole yksinäinen enää. / Että tässä on lähinnä vaan tää että kun sitten joutuu } \\
\text { niin karsittuu ympäristöön kuinka mä sanoisin. }\end{array}$ & $\begin{array}{l}\text { Yksinäiset tilat } \\
\text { ja paikat }\end{array}$ & \\
\hline $\begin{array}{l}\text { Saa olla aika paljon yksin huoneessa ennen kun joku tulee ja tekee jotain, } \\
\text { ja kiireesti pois taas. Sillon on kyllä yksinäisyys siinä. / Ku mä tulin tähän } \\
\text { taloon, ni se oli mulle aivan shokki, et kuinka dementoituneita ihmisiä täällä } \\
\text { on ja sit mä rupesin kiukutteleen siitä, ku ei oo ketään kenen kanssa juttelis. } \\
\text { Koska nää vanhukset oli semmosii et eihän niitten kanssa pystyny paljon } \\
\text { mitään puhumaan./ Kun joku mielenkiintoinen ohjelma televisiostakin } \\
\text { tulee ja kerätään niitä tuolissa istuvia sitten siihen ympärille, ei kestä } \\
\text { kauaa kun jotkut kuorsaa ja se harmittaa ihan. /Tääl on ihmiset kun ne } \\
\text { käy aamupuurolla, ne menee kiireesti huoneeseen, siellä ne on niin kauan, } \\
\text { sit se menee lounaalle, tulevat lounaalta, ovat huoneessaan, sit se tulee } \\
\text { päiväkahvin aika. Ei ku siel lounaan jälkeen mennään pitkälleen. / Että, koko } \\
\text { ajan vaihtuu henkilökunta että, melkein aina on, vieraita. }\end{array}$ & $\begin{array}{l}\text { Rutiininomaiset } \\
\text { vuorovaikutus- } \\
\text { tilanteet } \\
\text { asunnossa ja } \\
\text { sen ulkopuolella }\end{array}$ & \\
\hline
\end{tabular}

Ydinkategorioista "yksinäisyyden yksilöllinen luonne" oli aidoimmin aineistolähtöinen, sillä analyysia aloittaessamme emme vielä tienneet, miten palvelutalossa asuvat yksinäisyyttä kokevat. Huomasimme heidän kuvaavan sitä niin erilaisin ja omintakeisin sanakääntein, että päättelimme kokemusten olevan hyvinkin yksilöllisiä. Yksinäisyys on asia, jolle kukin antaa oman sisältönsä ja kokee sen omalla tavallaan - vaikka toisaalta yksinäisyyttä koskevien tunneilmauksien takana on varmasti myös tunnekonventioita, joka tuottavat ilmauksiin puheena ollutta toistoa.

Toistoa esiintyi erityisesti "yksinäisyys on sidoksissa aikaan" ja "yksinäisyys on sidoksissa paikkaan" -kategorioissa. Toistoa tuottivat haastateltavien muistivaikeudet, mutta sitä esiintyi myös kognitiivisesti toimintakykyisillä asukkailla. Ellemme olisi karsineet lähes samasanaisia aineisto-otteita, niistä olisi voi- nut muodostua neljäskin ydinkategoria: "konventionaaliset yksinäisyyden ilmaukset". Esimerkiksi yksinäisyyttä kuvaavia odottamiseen liittyviä ilmauksia esiintyi yli 30 aineistootteessa ja samalla henkilöllä parhaimmillaan seitsemässä otteessa. Jo tutkimuskysymyksistä lähtien kiinnostuksemme kohdistui kuitenkin yksinäisyyden ajallisiin ja paikallisiin yhteyksiin, joten päätimme keskittyä niihin.

\section{Tulokset}

\section{Yksinäisyyden yksilöllinen luonne}

Iäkkäiden ihmisten oma ääni oli helppo tuoda esille, niin rikkaasti yksinäisyyden kokemuksia kuvattiin. Haastateltavat käyttivät tietenkin paljon itse yksinäisyys-sanaa kuvaillessaan kokemuksiaan: Olen yksinäinen, Arki on niin yk- 
sinäistä. Mutta he käyttivät myös omintakeisia metaforia ja kielikuvia kuvatessaan yksinäisen oloa esimerkiksi kuin loskassa rämpimiseksi. Valoisassa talossa asuva "Tellervo" (kaikkien haastateltavien nimet on muutettu) puhui aidasta, jonka hän näki nousseen itsensä ja muiden asukkaiden väliin. Aita oli hänet eristänyt muista, tehnyt yksinäiseksi. Se oli vaikeuttanut kommunikaatiota ja omasta yksinäisyydestä puhumista:

\section{Tellervo: Kyllähän mulla kokemuksia riittää mis-} tä vois pubua, mutta kun mä en oo rybtyny, saanu sen aidan yli päästyä, joka estää mua pubumasta [muiden kanssa].

Tellervon mainitsema aita tuntui toisinaan nousseen myös haastateltavan ja haastattelijan väliin. Litteroinneista oli näet luettavissa, että ensimmäisellä haastattelukierroksella puolet haastateltavista puhui yksinäisyydestä varsin verhotusti ja yleisellä tasolla. He käyttivät kiertoilmauksia ja puhuivat mieluummin muiden yksinäisyydestä tai yksinäisyydestä yleensä kuin omasta yksinäisyydestään: Kaikki sitä tuntee ja sitä on aina. Ja just tää, tietysti ketkä on pyörätuolissa ja sänkyyn sidottuna. Että heillä ebkä on enemmän sitä yksinäisyyttä.

Kielentutkimuksessa on havaittu, kuinka kiertoilmauksien tehtävänä on kasvojen suojelu ja arkojen asioiden välttely (Varis 1998). Yksinäisyyskin saattaa olla arka, välteltävä asia, ja metodinen haaste sitä tutkittaessa on se, kuinka päästä aidan yli, kiinni todellisiin tuntemuksiin. Ihmisillä on taipumus kaunistella asioita puhuessaan tuntemattomien kanssa. Sanotaan että hyvää kuuluu, vaikka ei kuuluisikaan. Tällaisen aidan tai "onnellisuusmuurin" (happiness barrier) ylittäminen kysyy tutkijalta herkkyyttä ja sitkeyttä (Roos 1988).

Onnellisuusmuurin tai aidan ongelma oli tiedossa aineistoa kerättäessä, joten aidan yli yritettiin ja päästiinkin. Kun haastattelija tuli tutuksi, hänet päästettiin yksinäisyyskokemusten äärelle. Haastateltavilla ei ollut enää samanlaista tarvetta kiertoilmauksien käyttöön kuin aloitettaessa. Noin puolella haastateltavista sitä tarvetta ei tosin ollut ensimmäisessäkään haastattelussa. Heti kättelyssä he kertoivat yksinäisyydestään yllättävänkin avoimesti. Esimerkiksi valoisassa talossa asuva Lars sanoi suoraan, että hänen elämässään yksinäisyys on läsnä jok'ikinen päivä, vaikka hän oli esitietolomakkeeseen merkinnyt kärsivänsä yksinäisyydestä vain toisinaan. Larsin yksinäisyys oli kroonistunut ja alkanut painua hänen minuuteensa. Näin hän nimittäin itsensä määritteli: no mä oon vähän semmonen - yksinäinen ibminen.

Joillekin haastateltaville yksinäisyys oli kovin tunteellinen puheenaihe. Esimerkiksi valoisassa talossa asuva Alea istui ensimmäisen haastattelun alkaessa sänkynsä reunalla eikä juurikaan katsonut haastattelijaa silmiin. Kun yksinäisyys tuli puheeksi, hän kyyristyi polviensa päälle kuin suojaan käpertyäkseen. Hänen ilmeensä jähmettyi, ja vasta pitkän hiljaisuuden jälkeen hän henkäisi hiljaisella äänellä: No on jotenkin se arki vähän semmosta - yksinäistä. Mutta kun haastattelu eteni, Aleakin alkoi vapautua ja avautua. Kuten Kirkevold ja kumppanit (2013) toteavat, ihmiset ovat valmiit kuvailemaan arkana asiana pitämäänsä yksinäisyyttä, kunhan saavat tehdä sen turvallisessa ja heidän kokemuksiaan arvostavassa ilmapiirissä.

Pitkän talon asukkailla oli enemmän kognitiivisia kykyjä, ja heidän puheensa saattoi olla hyvinkin puntaroitua, kun he ilmaisivat oman ymmärryksensä yksinäisyydestä. Sofie yltyi hieman kritisoimaankin sitä, miten yliyksinkertaisesti häntä vanhemmat ihmiset ymmärtävät yksinäisyyden. Itse hän kohottautui tämän keskinkertaisena pitämänsä ajatusmaailman yläpuolelle.

Sofie: ... tää mua vanhempi ikäluokka on tottunu ajattelemaan, että yksinäisyys on paha ja ystävyys on byvä. Se on vähän sellast kliseistä ajattelua.

Emma puhui yksinäisyydestään korpeentumisena, vaikka teki samalla eräänlaista reflektiota pohtiessaan, onko sittenkään kyse yksinäisyydestä, hänestä kun korpeentuminen tuntui 
liittyvän toimintakyvyn muutoksiin ja elämänhallinnan puutteisiin. Siihen Emma kuitenkin päätyi, että

Emma: [...] kai sitä korpeentumista voi omalla tavallaan yksinäisyytenäkin pitää. Minusta käsite yksinäisyydestä on liian yksipuolinen. Korpeentuminen on sen ilmenemismuoto. Se on, enemmän ja enemmän, oman navan ympärillä pyörimistä. Se maailmanpiiri kapenee taikka kutistuu niin hirveesti.

Yksinäisyys on sidoksissa aikaan

Yksinäisyys näytti joillekin olevan jatkuva, toistuva ja syvälle painunut kokemus, toiset taas kokivat sitä vain ajoittain:

\section{Minä koen sitä aina \\ Minulla on sitä usein \\ Minä joskus koen sitä \\ Ei minulla sitä nyt ole.}

Yksinäisyyskokemuksen syvyys ja useus eivät vaihdelleet pelkästään interindividuaalisesti vaan myös intraindividuaalisesti, ajan mittaan. Esimerkiksi valoisassa talossa asuva Maria kuvaili yksinäisyyttään niin kuin olisi vain käynyt piipahtamassa kokemuksen reunalla: Ei minulla sitä nyt ole. Joskus se tuntuu, mutta kun ei siitä välitä. Toisessa yksilöhaastattelussa hän kuitenkin kuvasi sen krooniseksi sanoessaan elämänsä olevan jatkuvaa odottamista: Se on sitä yhtä vartoomista, kuule. Välillä vartoo tässä lääkkeitä ja kaikkea tommosta. Tää menee ihan vartoomiseksi. Alituinen odottelu onkin yksi $\mathrm{yk}^{-}$ sinäisyyden kokemuksen olomuoto, monelle tuttu. Lääkkeet kyllä tuodaan ja hoitotoimet tehdään ajallaan, mutta on myös odotuksia,jotka eivät tunnu koskaan täyttyvän. Aina ei edes tiedetä, mitä oikeastaan odotetaan (Karisto \& Tiilikainen 2017).

Yksinäisyys oli sidoksissa aikaan monin eri tavoin. Kokemukset vaihtelivat vuodenajan, viikonpäivien ja vuorokauden aikojen mukaan. Joskus tuntuu se yksinäisyys, että buomaa sen.
Varsinkin illalla. Erityisesti pimeä talviaika tuntui olevan monelle vaikeaa, mutta onneksi kevään tiedettiin kohta koittavan: No se [yksinäisyys] on ohimenevää, sitä nyt odottaa aina jotain kevättä ja kesää. Myös loma-ajat, juhlapyhät ja illat olivat haastavia, sillä silloin elämän tempo palvelutalossa hidastuu. On vähemmän henkilökuntaa, ei tapaa ihmisiä, ei ole tekemistä. Just lauantai ja sunnuntai on ne ikävät päivät. Katson että kyllä toisille tulee kyläilijöitä, minulle ei.

Yksinäisyyden kokemukset kiinnittyivät myös elämän kolmeen suureen aikahorisonttiin: menneeseen, nykyiseen ja tulevaan (Karisto \& Tiilikainen 2017). Vanhana palataan yleensäkin usein menneeseen, ja yksinäisyys alkaa painaa mieltä, kun havahtuu huomaamaan, että asiat eivät ole enää niin kuin ne ennen olivat tai niin kuin niiden muistetaan ennen olleen. Kadonnut aika ei palaa, eikä nykyinen aika tarjoa tarpeeksi. Tyypillistä on, että tulevaisuuskin tuntuu kaventuvan. Se, että vanhetessa tullaan tietoisiksi elämän rajallisuudesta, ilmeni aineistossa eräänlaisena eksistentiaalisena yksinäisyytenä (vrt. Kissane 2012).

Niin mä siitä yksinäisyydestä... Emmä tiä onks se sit sitä että.. kaikki ajattelee että tääbän nyt on joka tapauksessa tilapäistä että, ei tähän kannata kauheesti satsata. Ollaan kaikki aika lähellä kuolemista ja.. et ei tääl kauheen kauaa tarvi olla.

Muuan haastateltava sanoi suorasukaisesti, $m \ddot{a}$ haluisin päästä pois jo täältä maailmasta.

Aika ja paikka eivät ole toisistaan erillisiä, vaan pikemminkin toisiinsa kiinnittyneitä tai sulautuneita elämänpuitteita. Puhutaan aikamaisemasta (Adam 1995, 17; Karisto \& Tiilikainen 2017). Elämänkulkua on usein kuvattu spatiaalisin metaforin, erityisesti etenemisenä tietä tai polkua pitkin. Frits de Langen (2011) mukaan labyrintti on kuitenkin paljon parempi kielikuva kuvaamaan sitä aikamaisemaa, joka avautuu aktiivisesta toimijuudestaan jo tinkimään joutuneen vanhan ihmisen eteen. Labyrintissakin liikutaan, mutta ei vikkelästi ja 
lineaarisesti, vaan hitaasti ja haparoiden, joskus jumiin jääden. (Karisto \& Tiilikainen 2017.)

Yksinäisen aikamaisema voi näyttäytyä myös autiona tasankona, jossa ei juuri ole maamerkkejä, jotka helpottaisivat omaa paikantamista. Henna Mikkola (2005) päättelee omaelämäkerrallisten yksinäisyyskertomusten olevan ensisijaisesti kertomuksia itseä ympäröivästä tyhjyydestä, yksitoikkoisuudesta, tapahtumattomuutta ja hiljaisuudesta. Yksinäisen ajasta tulee hahmotonta, se venyy ja se käy pitkäksi. "Tunneista tulee hahmottomia, muodottomia, venyviä kuin kellot Salvador Dalin tauluissa." (Kapuscinski 1993, 36; Karisto \& Tiilikainen 2017.) Jennin eteen avautuva aikamaisema oli tämänkaltaista. Sairaus sai hänet juuttumaan pitkiksi ajoiksi ahtaaseen labyrinttiin, jopa samaan asentoon. Kun yksinäisen ihmisen liike oikein hiljenee ja uhkaa milteipä pysähtyä, hänen elämisensä muuttuu pelkäksi olemiseksi. Ihminen vieraantuu ympärillä olevasta ja myös itsestään.

\section{AJ: Sä sanoit et sä, jumitut tommosiin asentoibin pitkäks aikaa...}

Jenni: Joo puol tuntiiki oon ollu.

AJ: .... siinä kerkee monta ajatusta ajattelee.

Jenni: En mä tiiä. En mä paljo ajattele mittään.

AJ: Miltä se tuntuu ku siiben jää puoleks tunniks? Jenni: Ei sitä etukätteen tiedä, minkä aikaa se viipyy. Sitä kuvittelee et sitä pääsee irti heti, mutta ei sitä tiä. Puol tuntii mennee äkkiä. Ja kuulen ku tuo kello lyö aina. Se lyö puolen tunnin välein.

Yksinäisyyteensä jumittunut Jenni kuulee kyllä kellon lyönnit, mutta niiden välissä ei ole oikein mitään. Silloin ollaan vain paikallaan, yksinäisyyden ympäröimänä. Isommin ei liikkunut pitkässä talossa asuva Elisakaan. Hän vietti pitkiä aikoja istumalla puhelinpöytänsä ääressä, ratkoi sudokuja, söi ja joi kahvia, tai yksinkertaisesti vain istui ja katseli ulos ikkunasta.

Elisa: Ne sanoo että mikset sä voi tulla alas syömään, mut mä ajattelen, en miks mä istusin siellä syömässä kun mä voin istua ihan rauhassa tässä syömässä, ja jos joku soittaa, ja minä voin soittaa, ehkä.

Lainauksen päättävä ehkä-sana on oireellinen. Todellisuudessa Elisa soitti hyvin harvoin ja harvoin hän myös vastaanotti puheluita, vaikka hän niitä niin odotti, lapsiltaan. Silti puhelin oli hänelle"elämänlanka", jota pitkin saattoi periaatteessa olla yhteyksissä toisiin ihmisiin. Pelkästään tavoitettavissa oleminen oli Elisalle helpotuskeino. Puhelin edusti Elisalle potentiaalista toimijuutta (Pirhonen \& Pietilä 2016), vaikka se oli enimmäkseen hiljaa paikoillaan, niin kuin Elisakin oli.

Samanlaisen odotuksen muodon oli ottanut myös edellä jo kuvaamamme Jennin yksinäisyys. Hän odotti kovasti papin tulevan kylään, vaikka tiesi tämän olevan koko viikon lomalla.

Jenni: Tota pappia odotan. Pappi on käyny mua kerran viikkoon kattomas. Ei tule tänään tänne, mut mä kupit käskin laittaa valmiiks.

Karisto ja Tiilikainen (2017) tekivät vastaavan havainnon odottamisesta, jonka kohteena oli ovikellon soiminen: Nytkin taas tänään aattelin, että kun ei oo soinu toi ovikello, että onko patterit menny. Mä panin uudet patteritkin siihen, mut ei se soita silti. Ovikello, kahvikupit ja puhelin ovat potentiaalisen toimijuuden ja odotetun sosiaalisen vuorovaikutuksen välineitä. Toimijaverkkoteorian (Action network theory, $A N T$ ) valossa tällaiset artefaktit voivat olla toimijoita siinä kuin ihmisetkin (Latour 2005; Kela 2018).

Aineistomme valossa kokemus tyhjästä, yksinäisestä elämästä ei välttämättä ole yhteydessä siihen, kuinka aktiivinen iäkäs ihminen on. Esimerkiksi valoisassa talossa asuvan Marian ohjelmassa oli joka viikko jumppaa, bingo ja ryhmätapaamisia, mutta tunne jatkuvasta vartoomisesta oli silti hänen päällimmäinen kokemuksensa elämästä. Voikin olla paradoksaalisesti jopa niin, että erilaisten aktiviteettien alle kätkeytyy tyhjyyttä ja merkityksettömyyttä. 
Aikaisemmin vanhuuden ajateltiin olevan irtaantumisen aikaa, mutta nyt vanhojen odotetaan touhuavan ja olevan kiireisiä (Katz 2000). Aktiivisesta ikääntymisestä on tullut aikamme mallivanhuutta (Timonen 2016), mutta kaikista ei vain ole aktiivisiksi. Voidaan kokea, että kun ympärillä tempo kiihtyy ja muiden aika kulkee aina vain nopeammin, oman elämän rytmi tuntuu sitäkin hitaammalta ja elämä tyhjemmältä.

Toisaalta aika voi myös parantaa. Esimerkiksi Sofien yksinäisyyden kokemukset tuntuvat helpottuneen ajan myötä

Sofie: Mut se mikä on jännä, et näköjään aika auttaa paljon. Mä en ollu ybtään varma siitä ku mulle sanottiin, et oota, kyllä se tästä helpottuu. Niin se vaan näköjään on tapabtunu.

Mutta aika voi myös aukaista arpeutuneita haavoja. Näin oli käynyt Emmalle, jolle nuoruuden yksinäisyyden kokemukset nousivat pintaan elämänhallinnan ja toimintakyvyn heikennyttyä. Myös Tiilikainen ja Seppänen (2017) kuvailevat, kuinka elämänkulun aikaisemmat tapahtumat voivat synnyttää ja ylläpitää myöhempää yksinäisyyttä.

\section{Yksinäisyys on sidoksissa paikkaan}

Yksinäisyyden tunnot voivat kummuta siitä, että olemisen paikka koetaan outona ja vieraana. Kovin kotoisaa ei elämä palvelutalossa välttämättä ole, vaikka kodinomaisuus on palveluasumisen tavoitteena ja asukkaiden korostetaan asuvan omissa kodeissaan. Palvelutalot eivät välttämättä ole "riittävästi koteja" (Vilkko 2000) tai kyllin hyviä kodin korvikkeita. Hätkähdyttävää oli huomata, että yksikään tähän tutkimukseen osallistuneesta 13 asukkaasta ei pitänyt palvelutaloa tai asuntoaan kotinaan. Kun kodista puhuttiin, tarkoitettiin aina aikaisempaa asuinsijaa, sitä oikeaa kotia, josta oli jouduttu luopumaan ja joka oli muuttunut kaipuun kohteeksi. Joskus minä kaipaan sinne kotiin.. kaikki vanhat muistot elää siellä...
Cooney (2012) kuvaa koti-ikävää,jota pitkäaikaishoivan piirissä olevat potevat. Yksinäisyyttä ilmaistaan puhumalla kotiin menemisestä (going home), toiveesta päästä pois siitä yksinäisyyden merkitsemästä paikasta,jossa nyt ollaan. Tähän tutkimukseen osallistuneet eivät kotiin menemisestä juuri puhuneet, mutta palvelutalo oli monille paikka, josta huokui yksinäisyyttä. Hanna puki tämän suuntaisen kokemuksensa sanoiksi: Varsinki tällases paikkaa sitä voi tuntea olonsa välillä todella yksinäiseks.

Ei ole elämä omassa yksityiskodissakaan välttämättä helppoa, jos siellä ei enää pärjää. Kodissa vallitsee kuitenkin läsnäolon kokemus, joka tutkimukseen osallistuneilla oli heikko. Erityisesti pitkässä talossa asuvat kokivat itsensä näkymättömiksi, läsnäolon tunteen menettäneiksi: Minkä takia ku talossa asuu niin ei kiinnitetä huomioo, et ihminen häviää? Kokemukset siitä, että palvelutalossa asuvat eivät koe tulevansa huomioiduksi omina ainutkertaisina yksilöinä, juontuivat osittain siitä, että kanssakäyminen henkilökunnan kanssa ei aina sujunut parhaalla mahdollisella tavalla. Havainnointiaineistoon kertyi esimerkkejä siitä, että henkilökuntaan kuuluva saattoi tulla asukkaan asuntoon joitakin työtehtäviä tehdäkseen, mutta omilla avaimillaan ja tulonsa syystä mitään kertomatta. Ei ihme, että asuntoa ei silloin pidetty kotina, eihän toisen kotiin voi noin vain mennä.

Kokemuksia siitä, että palvelutalon asukasta ei kohdata ja kohdella ainutkertaisena persoonana (ks. Pirhonen 2017) kertyi erityisesti pitkässä talossa: Meidät pistetään semmosiin lokeroibin. Luukusta ruokaa. Pitkän talon ankeahko ympäristö saattoi vaikuttaa kokemuksiin, joskin voi olla myös niin, että sen kognitiivisesti kyvykkäämmät asukkaat osasivat paremmin tuoda esille huonoja kokemuksiaan.

Kaiken kodikkuuden ei sentään koettu kummastakaan talosta kaikonneen. Kerrottiin myös taloissa tapahtuneista yksinäisyyttä lievittävistä ihmiskontakteista, esiteltiin asunnon itselle tärkeää ja mieltä lämmittävää esineympäristöä, kuten valokuvia, tauluja ja muita taide-esinei- 
tä sekä huonekaluja. Jennille kellot tekkee niin kodikkaaks olon. Täällä raksuttaa kellot tosiaan, monta kelloo on raksuttamassa.

Itselle tärkeät esineet aktivoivat muistoja ja tuovat nykyiseen entisen elämän aineksia (Nord 2013). Nekään eivät palvelutaloa kuitenkaan kodiksi muuta. Palvelutaloa ja omaa asuntoa kuvattiinkin lähinnä kielteisin sanakääntein sairaalaksi, vankilaksi, markkinatoriksi, varastoksi, kopiksi, mökiksi tai yksinkertaisesti asunnoksi ja huoneeksi, mutta ei vahingossakaan kodiksi. Nämä karut ja karkeat ilmaukset viittaavat siihen, että asuinympäristö ruokkii huonoja kokemuksia ja ne puolestaan värittävät käsityksiä asuinympäristöstä. Kyse ei ollut yleisestä tyytymättömyydestä tai pahantuulisesta narinasta, sillä asumisen koettuja epäkohtia konkretisoitiin monin tavoin. Erityisesti se, että asunnossa jouduttiin olemaan pitkään eikä päästy ulos tarpeeksi usein, kirvoitti sarkastisia ja kriittisiä kommentteja.

Paremmat niil on vankilassa ku meil on oltavat. Pääsevät kaks kertaa viikossa suibkuun ja joka päivä ulkoilutetaan. ...Saa olla aika paljon yksin buoneessa, ennen kun joku tulee ja tekee jotain, ja kiireesti pois taas. Sillon on kyllä yksinäisyys siinä.

Aikaisemmissakin tutkimuksissa (Drageset, Kirkevold \& Espehaug 2011, Prieto-Flores ym. 2011) on tullut esille se, että ihmiskontaktien laatu on vähintään yhtä tärkeää kuin niiden määrä. Jos kohdattaessa toinen vain ohitetaan, tiheäkään kohtaaminen ei välttämättä lievitä yksinäisyyttä.

Pitkä talo jakautui hyvin jyrkästi yleisiin ja yksityisiin tiloihin. Ei ollut riittävästi julkisen ja yksityisen tilan välissä olevaa puolijulkista tai niin sanottua kolmatta tilaa (Oldenburg 1989), joka mahdollistaa spontaanit kontaktit ja kohtaamiset (Cooney 2012, Prieto-Flores ym. 2011). Palvelutalossa on paljon toisia ihmisiä, mutta ei tarpeeksi sellaisia toisia, joiden kanssa puhellaan ja ollaan merkityksellisesti tekemisissä. Ystäväpiiri-ryhmissäkin osoittautui, että osallistujat eivät ennestään tunteneet toi- siaan, mutta onneksi he tutustuivat prosessin kuluessa (Jansson, Karisto \& Pitkälä 2019b). Palvelutalon asukkaiden keskinäinen yhteydenpito onkin avainasemassa asukasviihtyvyyttä lisättäessä sekä yksinäisyyttä ennaltaehkäistäessä ja lievitettäessä (Fessman \& Lester 2000; Slettebø 2008; Prieto-Flores ym. 2011; Cooney 2012).

Erilaista yhteistä toimintaa tutkimissamme palvelutaloissa on toki tarjolla, mutta esimerkiksi Emma toi esille sen, että ei ole niin helppoa liittyä uutena jäsenenä jo olemassa oleviin ryhmiin.

Emma: Sitte ku menee uutena johonkin rybmään, joka on jo koossa niin ei ole helppo päästä sisään. Senbän takia ibmiset ei läbtiskään minnekään palvelutaloibin ja vanhainkoteibin että ne olis kotona viimeseen saakka.

Sofie purki avoimesti pettymystään muihin talon asukkaisiin.

Sofie: Ku mä tulin tähän taloon, ni se oli mulle aivan shokki, et kuinka dementoituneita ibmisiä täällä on ja sit mä rupesin kiukutteleen siitä, ku ei oo ketään kenen kanssa juttelis. Koska nää vanhukset oli semmosii et eibän niitten kanssa pystyny paljon mitään pubumaan.

Jotkut siis kokivat ympärillä olevat ihmiset vaikeasti lähestyttävinä. Puoleensa vetävinä ei pidetty liioin oman asunnon ulkopuolisia tiloja. Etenkään pitkän talon autiot käytävät eivät houkutelleet poistumaan asunnosta. Oli myös kokemuksia siitä, että käytävällä vain mölytään. Eleonoora ihmetteli, mihin hän voisi mennä, kun yksinäisyyden tunne iskee.

Eleonoora: En mibinkään. Pitäs olla joku semmonen tila, missä vois istua. Pitäs olla joku määrätty aika että jokainen sitten joka haluaa, tulis silloin sinne.

Käytävillä oli kyllä oleskelutiloja ja sohvaryhmiä, mutta ne olivat yleensä tyhjiä. Ja vaikka 
hoitajat tarkoituksella kokosivat valoisan talon asukkaita TV:n ääreen, kunnon sosiaalista vuorovaikutusta ei silloinkaan syntynyt.

Kun joku mielenkiintoinen objelma televisiostakin tulee ja kerätään niitä tuolissa istuvia sitten siihen ympärille, ei kestä kauaa kun jotkut kuorsaa ja se harmittaa iban.

Pääseminen ulos edusti tutkittaville myös ulospääsyä yksinäisyydestä.

Hanna: No sebän [yksinäisyys] on tietysti silloin tällöin kun ei jaksa läbtee. [...]Otan auton ja ajan kauppakeskukseen, kattelen näyteikkunoita, juon teetä. Mä siellä muutaman tunnin oon, tilaan auton ja tulen pois. Päivä on taas pelastettu.

Kauppakeskus tarjosi Hannalle paikan, jossa viihtyä. Hän kykeni poistumaan palvelutalosta, mutta monet muut eivät kyenneet: en voi mennä ulos yksin, kun minua huimaa. Ulosmenon esti oma kunto ja talviaikaan esimerkiksi kävelyteiden liukkaus, mutta esteet eivät olleet yksin fyysisiä

Mul on jotenki semmonen käsitys, että monelle on tullu se kynnys liian korkeeksi, et on liikaa siellä asunnossaan. Se on se suurin juttu. Ja sen ulkopuolelle kun pääsee niin se tilanne muuttuu. Kun pääsee kerran menemään niin huomaa, että mäbän voinkin mennä, mäkin voinkin läbtee tästä.

Palvelutalon ulko-ovella oli psykologisiakin kynnyksiä. Yllättävä ulos menemisen este oli luulo siitä, ettei poistuminen ole edes sallittua: Tuli sitten uus asiakas ja bän oli näbny, että mä lähen. Se sano että, saako täältä läbteeki johonkin.

Periaatteessa ulos lähteminen oli tietenkin mahdollista niille, joiden fyysinen ja henkinen toimintakyky sen sallivat. Käytännössä se ei ollut kuitenkaan yksinkertaista. Tauben ja muiden (2016) mukaan toimintakyvyn heikentyminen ja sosiaalisten suhteiden ohentuminen saa juuttumaan "kuplaan", josta ei ole välttämättä ulospääsyä ja jonka yksinäisyyden ko- kemukset helposti täyttävät. Tällaista kuplaa voivat virittää niin palvelutalon toimintakäytänteet kuin asukkaiden fyysisen ja henkisen toimintakyvyn rajoitteetkin. Kupla ei vain saisi kasvaa sellaiseksi, että se ei ole enää puhkaistavissa.

\section{Yhteenveto}

Rikkaaseen aineistoon perustuva tutkimuksemme toi näkyville ja toivon mukaan myös välitti lukijoille yksinäisyyden kokemuksia, joita palvelutalossa asuvilla iäkkäillä ihmisillä on. Haimme vastauksia siihen, millaista palvelutaloissa koettu yksinäisyys on ja miten se on yhteydessä aikaan ja paikkaan.

Yksinäisyyden tunnot tulvahtivat ilmoille erityisesti iltaisin, viikonloppuisin ja talviaikaan. Yksinäisyys oli yhteydessä aikaan myös abstraktimmalla tavalla. Kokemus siitä, että oma aika kulkee hitaasti, sai tuntemaan itsensä yksinäiseksi. Myös epämääräinen kokemus jonkin odottamisesta oli tuttua yksinäisille. Elämä tuntui tyhjentyneen merkityksellisyydestä. Yksinäisyyden kokemuksia tuotti myös aikahorisonttien, erityisesti tulevaisuuden, kapeneminen. Vanhetessa oltiin tultu tietoisiksi elinajan rajallisuudesta, kuolemaa saatettiin jopa odottaa.

Yksinäisyyttä synnytti myös se, että palvelutalo on paikka, jossa ei oikein koeta oltavan kotonaan. Etenkään tutkimaamme "pitkää taloa" ei pidetty kotina eikä edes kodinomaisena. Kodittomuuden tunne ilmeni esimerkiksi niin, että kukaan kolmestatoista tutkittavasta ei kutsunut omaa asuntoaan kodiksi. He asuivat paikassa, johon eivät olleet kotiutuneet ja jossa he kokivat muuttuneensa jotenkin näkymättömiksi, joutuneensa oman elämänsä sivustakatsojiksi. Palvelutalosta ei päästy ulos siinä määrin kuin sitä odotettiin, ja tämäkin vahvisti kokemusta, että yksinäisyydestä ei ole ulospääsyä.

Tutkimuksemme vahvistaa aikaisempia tutkimustuloksia siitä, että yksin asuminen tai erillään olo muista (social isolation) tulee erot- 
taa koetusta yksinäisyydestä. Ne toki liittyvät yksinäisyyteen, mutta ovat silti eri asioita. Tutkimuksemme osallistujat kokivat yksinäisyyttä ollessaan muiden ihmisten ympäröiminä, vaikka heillä oli arjen aktiviteettejakin. Tämä kertoo siitä, että päätelmiä toisen ihmisen yksinäisyydestä ei voi tehdä vain ulkoisten merkkien tai olosuhteiden perusteella. Siitä on kysyttävä suoraan, mutta niin, että kokemuksista uskaltaa puhua. Me puhutimme palvelutaloasukkaita tutkimustarkoituksissa, mutta yksinäisyyden kokemuksia on syytä seuloa myös palvelutalojen arjessa. Kehitettäessä hoivakäytäntöjä on kehitettävä myös yksinäisyyden kartoittamisen ja kirjaamisen keinoja sekä toimia sen lievittämiseksi.

Tutkimustuloksemme eivät tietenkään ole koko totuus palvelutaloista, niiden asukkaista, kulttuureista ja käytänteistä. Aineistomme oli valikoitunut siten, että tutkittavina olivat vain ne, jotka ennalta tiedettiin yksinäisiksi. Ne palvelutalojen asukkaat, jotka eivät kärsi yksinäisyydestä, voivat tuntea palvelutalon paremmin kodikseen. He voivat arvioida siellä vietettyä elämää eri tavoin kuin tämän tutkimuksen haastateltavat. Tässä aineistossa yksinäisyys kuitenkin näyttäytyi niin voimakkaana kokemuksena, että se on otettava vakavasti. Palvelutaloissa vallitsevaa yksinäisyyttä voidaan lievittää ja elämänlaatua parantaa suunnittelemalla talot ja niiden toiminnot aikaisempaa paremmin. Tilojen toimivuus, estetiikka ja symboliikka eivät ole ollenkaan yhdentekeviä. Ja

\section{Kirjallisuus}

Adam, B. (2004). Time. Cambridge: Polity Press.

Aro, L. (1996). Minä kylässä. Identiteettikertomus haastattelututkimuksen folklorena. Helsinki: Suomalaisen Kirjallisuuden Seura.

Brownie, S. \& Horstmanshof, L. (2011). The management of loneliness in aged care residents: an important therapeutic target for gerontological nursing. Geriatric Nursing, 32 (5), 318-25. doi: 10.1016/j.gerinurse.2011.05.003. jos palvelutaloasuntoja kodeiksi kutsutaan, pitää kodin yksityisyyttä myös käytännössä kunnioittaa.

Palvelutalossa asuvan henkilön elämänkulkua määrittää kaksi merkittävää rajapyykkiä. Toinen niistä, omasta kodista pois muuttaminen, on tapahtunut lähimenneisyydessä. Toinen, viimeinen rajapyykki, on puolestaan lähestyvä kuolema. Jotta iäkkään ihmisen elämä näiden rajapyykkien välillä olisi mahdollisimman merkityksellistä ja mielekästä, vailla yksinäisyyttä, palvelutalojen tavoitelausumien olisi syytä toteutua. Entinen elämänpiiri ei saisi kaventua palvelutaloon muutettaessa eikä palvelutalo leikkautua irti ympäristöstään ja muusta yhteiskunnasta. Yhteydet talon sisällä tapahtuvaan ja ulkopuoliseen sosiaaliseen elämään, lähiympäristöön ja luontoon tulee turvata.

\section{Artikkelin käsikirjoituksen tukemisesta apurabojen} muodossa osoitetaan parhaimmat kiitokset Miina Sillanpään säätiölle, Olvi-säätiölle, Orionin tutkimussäätiölle sekä Signe ja Ane Gyllenbergin säätiölle. Tutkimusluvat: HUS 1150/2016, päivätty 8.11.2016 ja Helsingin kaupunki, HEL 2016-014058, päivätty 3.1.2017

\section{Yhteydenotto}

Anu Jansson, TtM (Gerontologi), väitöskirjatutkija Yleislääketieteen ja perusterveydenhuollon osasto Helsingin yliopisto anu.jansson@vtkl.fi

Cacioppo, J. T. \& Hawkley, L. C. (2009). Perceived social isolation and cognition. Trends in Cognitive Sciences, 13 (10), 447-454. doi: 10.1016/j.tics.2009.06.005.

Charmaz, K. \& Mitchell, R. (2002). Grounded Theory in Ethnography. Teoksessa Atkinson, P., Coffey, A., Delamont, S., Lofland, J., \& Lofland, L. (toim.), Handbook of ethnography (s. 160-170). London: SAGE Publications. 
Cooney, A. (2012). 'Finding home': a grounded theory on how older people 'find home' in long-term care settings. International Journal of Older People Nursing, 7, 188-199.

doi: 10.1111/j.1748-3743.2011.00278.x.

De Lange, F. (2015). The End of Straightforward Living. Labyrinthe Ageing. 8th International Conference on Cultural Gerontology, Meaning and Culture(s): Exploring the Life Course. Galway, Ireland, 10.-12.4.2014.

Drageset, J., Kirkevold, M. \& Espehaug, B. (2011). Loneliness and social support among nursing home residents without cognitive impairment: A questionnaire survey. International Journal of Nursing Studies, 48, 611-619. doi: 10.1016/j.ijnurstu.2010.09.008.

Drageset, J., Eide, G. E., Kirkevold, M. \& Ranhoff, A. H. (2012). Emotional loneliness is associated with mortality among mentally intact nursing home residents with and without cancer: a fiveyear follow-up study. Journal of Clinical Nursing, 44, 106-114. doi: 10.1111/j.1365-2702.2012.04209.x.

Fessman, N. \& Lester, D. (2000). Loneliness and depression among elderly nursing home patients. The International Journal of Aging and Human Development, 51, 137-41.

doi: 10.2190/5VY9-N1VT-VBFX-50RG.

Foley, G. \& Timonen, V. (2015). Using Grounded Theory Method to Capture and Analyze Health Care Experiences. Health Services Research, 50 (4), 1195-1210. doi: 10.1111/1475-6773.12275.

Gerst-Emerson, K. \& Jayawardhana, J. (2015). Loneliness as a Public Health Issue: The Impact of Loneliness on Health Care Utilization among Older Adults. American Journal of Public Health, 105 (5), 1013-1019.

doi: 10.2105/AJPH.2014.302427.

Heyl, B. (2001). Ethnographic Interviewing. Teoksessa Atkinson, P., Coffey, A., Delamont, S., Lofland, J., and Lofland, L. (toim.), Handbook of Ethnography. Handbook of ethnography (s. 369383). London: SAGE Publications.

Hwang, S. (2008). Utilizing Qualitative Data Analysis Software: A Review of Atlas.ti. Social Science Computer Review, 26 (4), 519-527. doi: 10.1177/0894439307312485.

Jansson, A. H., Muurinen, S., Savikko, N., Soini, H., Suominen, M. M., Kautiainen, H. \& Pitkälä, K. H. (2017). Loneliness in nursing homes and assisted living facilities: prevalence, associated fac- tors and prognosis. Journal of Nursing Home Research, 3, 43-49. doi: 10.14283/jnhrs.2017.7.

Jansson, A., Savikko, N. \& Pitkälä, K. (2018). Training professionals to implement a group model for alleviating loneliness among older people 10-year follow-up study, Educational Gerontology, 44 (2-3), 119-127.

doi: 10.1080/03601277.2017.1420005.

Jansson, A., Karisto, A. \& Pitkälä K. (2019a). Timeand place-dependent experiences of loneliness in assisted living facilities. Ageing and Society, painossa. doi:10.1017/S0144686X19001211.

Jansson, A., Karisto, A. \& Pitkälä K. (2019b). Loneliness in assisted living facilities: An exploration of the group process. Scandinavian journal of occupational therapy. England: Scandinavian University Press. doi: 10.1080/11038128.2019.1690043. Kapuscinski, R. (1994). Imperium. London: Granta.

Karisto, A. (2008). Satumaa. Suomalaiseläkeläiset Espanjan Aurinkorannikolla. Helsinki: Suomalaisen Kirjallisuuden Seura.

Karisto, A. \& Tiilikainen E. (2017). Yksinäisyys ja aika. Yhteiskuntapolitiikka, 82 (5), 527-537.

Katz, S. (2000). Busy bodies: Activity, aging and management of everyday life. Journal of Aging Studies, 14 (2), 135-152.

doi: 10.1016/S0890-4065(00)80008-0.

Kela, R-L. (2018). Kelpoisia kokoonpanoissaan. Aineistolähtöinen tutkimus siitä, miten tapahtuu muistisairauden sosiaalinen. Pro gradu -tutkielma. Helsingin yliopisto, Valtiotieteellinen tiedekunta, Sosiaalitieteiden laitos. Saatavilla http://urn.fi/URN:NBN:fi:hulib-201812043640.

Kissane, D.W. (2012). The relief of existential suffering. Archives of internal medicine, 172 (19), 15011505. doi: 10.1001/archinternmed.2012.3633.

Kirkevold,M.,Moyle, W., Wilkinson, C., Meyer,J. \& Hauge, S. (2013). Facing the challenge of adapting to a life 'alone' in old age: the influence of losses. Journal of Advanced Nursing, 69, 394-403. doi: 10.1111/j.1365-2648.2012.06018.x.

Laki ikääntyneen väestön toimintakyvyn tukemisesta sekä iäkkäiden sosiaali- ja terveyspalveluista 980/2012.

Latour, B. (2005). Reassembling the Social. An Introduction to Actor-Network-Theory. Oxford: Oxford University Press.

Luanaigh, C. O. \& Lawlor, B. A. (2008). Loneliness and the health of older people. International Journal of Geriatric Psychiatry, 23, 1213-1221. doi: 10.1002/gps.2054. 
Mikkola, H. (2005). Yksinäisyyden verho ympärillä ihmisten ohi kuljen - yksinäisyyskertomukset Sukupolveni unta -kirjoituskilpailuaineistossa. Teoksessa Jokinen, K. (toim.), Yksinäisten sanat. Kirjoituksia omasta tilasta, erillisyydestä ja $y k-$ sinolosta. Jyväskylä: Gummerus, 129-187.

Mirza, N. A., Akhtar-Danesh, N., Noesgaard, C., Martin, L. \& Staples, E. (2014). A concept analysis of abductive reasoning. Journal of Advanced Nursing, 70 (9), 1980-1994. doi: $10.1111 /$ jan.12379.

Mäntyranta, T. \& Kaila, M. (2008). Fokusryhmähaastattelu laadullisen tutkimuksen menetelmänä lääketieteessä. Lääketieteellinen aikakauskirja Duodecim, 124 (13), 1507-1513.

Nikander, P. (2014). Laadullinen pitkittäistutkimus ja terveys. Sosiaalilääketieteellinen aikakauslehti, Metodinumero 51, 243-252.

Nord, C. (2013). A day to be lived. Elderly peoples' possessions for everyday life in assisted living. Journal of Aging Studies, 27 (2), 135-142. doi: 10.1016/j.jaging.2012.12.002.

Nyqvist, F., Cattan, M., Andersson, L., Forsman, A. K. \& Gustafson, Y. (2013). Social Capital and Loneliness among the Very Old Living at Home and in Institutional Settings: A Comparative Study. Journal of Aging and Health, 25 (6), 10131035. doi: $10.1177 / 0898264313497508$.

Oldenburg, R. (1989). The Great Good Place. Cafes, Coffee Shops, Community Centres, General Stores, Bars, Hangouts, and How They Get You through the Day. New York: Paragon House.

Pirhonen, J. (2017). Good Human Life in Assisted Living for Older People. Acta Universitatis Tamperensis 2272. Tampere: Tampereen yliopisto.

Pirhonen, J. \& Pietilä, I. (2016). Perceived residentfacility fit and sense of control in assisted living. Journal of Aging Studies, 38, 47-56. doi: 10.1016/j.jaging.2016.04.006.

Pirhonen, J., Tiilikainen, E. \& Pietilä, I. (2017). Ruptures of affiliation: social isolation in assisted living for older people. Ageing E Society, 38 (9), 1868-1886. doi: https://doi.org/10.1017/ S0144686X17000289.

Prieto-Flores, M. E., Fernandez-Mayoralas, G., Forjaz, M. J., Rojo-Perez, F. \& Martinez-Martin, P. (2011). Residential satisfaction, sense of belonging and loneliness among older adults living in the community and in care facilities. Health Place, 17 (6), 1183-1190.

doi: 10.1016/j.healthplace.2011.08.012.
Roos, J. P.(1998). Behind the happiness barrier. Social Indicators Research, 20 (2), 141-163. doi: 10.1007/BF00302459.

Roth, E. G. \& Eckert, J. K. (2011). The vernacular landscape of assisted living. Journal of Aging Studies, 25 (3), 215-224. doi: 10.1016/j.jaging.2011.03.005.

Routasalo, P.E., Savikko, N., Tilvis, R. S., Strandberg, T. E. \& Pitkälä, K. H. (2006). Social contacts and their relationship to loneliness among aged people - a population-based study. Gerontology, 52 (3), 181-187. doi: 10.1159/000091828.

Saari, J. (2016). Suomalaisten yksinäisyys. Teoksessa Saari J. (toim), Yksinäisten Suomi (s. 33-51). Helsinki: Gaudeamus.

Savikko, N. (2008). Loneliness of older people and elements of an intervention for its alleviation. Turun yliopiston julkaisuja, Sarja D, Osa 808. Turku: Turun yliopisto.

Savikko, N., Routasalo, P., Tilvis, R. S., Strandberg, T. E. \& Pitkälä, K. H. (2005). Predictors and subjective causes of loneliness in an aged population. Archives of Gerontology and Geriatrics, 41,223-233. doi: 10.1016/j.archger.2005.03.002.

Savikko N., Jansson A. \& Pitkälä K. (2019). Yksinäisyys on kognition heikkenemisen merkittävä riskitekijä ikääntyneellä. Lääkärilehti, 19, 38-43.

Slettebø, Å. (2008). Safe, but lonely: Living in a nursing home. Vard i Norden, 87 (28), 22-25. doi: 10.1177\%2F010740830802800106.

Smith, K. J. \& Victor, C. (2018). Typologies of loneliness, living alone and social isolation, and their associations with physical and mental health. Ageing E Society, 4 (10), 1-22. doi: 10.1017/S0144686X18000132.

Taube, E., Jakobsson, U., Midlöv, P. \& Kristensson, J. (2016). Being in a Bubble: the experience of loneliness among frail older people. Journal of $A d-$ vanced Nursing, 72 (3), 631-640. doi: https://doi.org/10.1111/jan.12853.

Tiilikainen, E. \& Seppänen, M. (2017). Lost and unfulfilled relationships behind emotional loneliness in old age. Aging E Society, 37, 1068-1088. doi: 10.1017/S0144686X16000040.

Tiilikainen, E. (2016). Yksinäisyys ja elämänkulku. Laadullinen seurantatutkimus ikääntyvien yksinäisyydestä. Valtiotieteellisen tiedekunnan julkaisuja. Helsinki: Unigrafia.

Tilvis, R. S., Routasalo, P., Karppinen, H., Strandberg, T. E. \& Pitkälä, K. H. (2011). Social isolation, social activity and loneliness as survival indica- 
tors in old age; a nationwide survey with a 7-year follow-up. European Geriatric Medicine, 3, 18-22. doi: 10.1016/j.eurger.2011.08.004.

Timonen, V. (2016). Beyond Successful and Active Ageing: A Theory of Model Ageing. Bristol: Policy Press. Vaarama, M., Mukkila, S. \& Hannikainen-Ingman, K. (2014). 80 vuotta täyttäneiden elämänlaatu ja elinolot. Teoksessa Vaarama, M., Karvonen, S., Kestilä, L., Moisio, P., Muuri, A. (toim.), Suomalaisten byvinvointi (s. 40-58). Helsinki: Terveyden ja hyvinvoinnin laitos.
Varis, M. (1998): Sumea kieli. Kiertoilmauksen muoto ja intentio nykysuomessa. Helsinki: Suomalaisen Kirjallisuuden Seura.

Vilkko, A. (2000). Riittävästi koti. Janus, 8 (3), 213230.

Yang, K. \& Victor, C. (2011). Age and loneliness in 25 European nations. Aging E Society, 31 (8), 13681388. doi: 10.1017/S0144686X1000139X. 